Journal of Economics and Behavioral Studies

Vol. 6, No. 7, pp. 591-606, July 2014 (ISSN: 2220-6140)

\title{
Trade liberalization, Economic Growth and Poverty Level in Nigeria: Vector Auto-regression (VAR) Approach (1980-2009)
}

\author{
Aremo, Adeleke Gabriel \\ Obafemi Awolowo University, Ile-Ife, Nigeria \\ aremoa@oauife.edu.ng
}

\begin{abstract}
The paper examines the nexus among trade liberalization, economic growth and poverty level in Nigeria between 1980 and 2009 within the context of multivariate Vector Auto regression (VAR) with a view to establishing the links that exist among the three variables. The data series were also subjected to unit root and co integration tests to examine the properties of the data. The findings that emerged from the analyses showed that the interactions among trade liberalization, economic growth and poverty level suggest that economic growth had a positive impact on trade liberalization in Nigeria within the study period. Also, the interactions among trade liberalization, economic growth and poverty level were weak making the effect of trade liberalization on poverty to be low. This probability portrays the presence of some structural rigidity in the economy capable of preventing the impact of trade liberalization from being fully felt on poverty, particularly through economic growth channel. This suggests the presence of some institutional factors that create inherent problems in the economy that could largely frustrate any valid and sincere trade policies formulated by the government. It is therefore recommended that policy makers should be mindful of the fact that the Nigerian economy is structurally vulnerable; such that for any policy to succeed, the peculiar characteristics of the economy must be factored into the plan and rigorously evaluated for good policy effects.
\end{abstract}

Keywords: Trade liberalization, Economic growth, Poverty level, Vector Auto regression.

\section{Introduction}

Evidence from the literature has failed to establish any valid relations between trade liberalisation and economic growth. Also, there is weak evidence that openness is associated with higher growth (Mbabazi, Morrisey and Milner, 2001). The general empirical facts however have shown that trade liberalisation fosters increasingly competitive environment leading to a more efficient allocation of resources. This promotes constant innovation and higher level of foreign financial aid for productivity and equally provides a necessary condition for attaining convergence with developed economy. Besides, trade liberalisation has increasingly become a necessary condition for developing economies' eligibility for foreign financial aid (Sachs and Warner, 1995). There are equally controversies in the literature on the relationship between economic growth and poverty. On critical examination, it appears that economic growth should necessarily reduce poverty, yet the issue remains largely unsettled. Some scholars asserted that economic growth does not eliminate poverty, and could even exacerbate the problem of the poor (United Nations, 1997). Scholars like Dreze and Sen (1990) argued that economic growth would not produce any benefits in terms of nonmonetary measures of well-being. Based on this, scholars had advocated increased government spending or any forms of equitable wealth redistribution strategies (Todaro, 1997). The argument of Todaro that economic growth does not favour poverty reduction is based on the fact that the growth process does not trickle-down to the poor, but it rather trickles-up to the middle classes, especially the very rich.

A large body of evidence from the literature has shown that poverty reduction is enhanced through economic growth. This opinion is attested to by empirical works that are available in the literature which are largely based on cross-country regression. For instance, Dollar and Kraay (2000, 2001 and 2004) were of the opinion that on the average across countries and overtime, growth is distribution neutral. On the basis of this, any factor that would increase growth rate is recommended for poverty reduction. They believed that the World Bank and IMF policy packages, including trade liberalisation, are recommended panacea for poverty reduction and should necessarily be the core of poverty reduction strategies. Other studies with similar 
findings are Case (2000), Dercon (2001), and Lanchovichina, Nicita and Soloaga (2001) which are consistent with Dollar and Kraay (2004). Other studies in this category include: Ravallion and Datt (1996), Dollar and Kray (2002), Tendulkar (1998), and Bhagwati (2001). The issue emerging from the above discussions is that existing literature is yet to arrive at a consensus on the nature of the relationship between trade liberalisation and economic growth; trade liberalisation and poverty; and economic growth and poverty; thus the need to investigate this links among these variables. Also, given that it has been established in the literature that economic growth is one of the channels through which trade liberalisation could impact on poverty level, it is equally relevant to attempt to investigate the impact of trade liberalisation on poverty through the economic growth process. The remaining sections are organised into five sections. In section 2, a brief summary of the theoretical and empirical issues on the relationship between trade liberalisation, economic growth and poverty level is provided. The specification of the model is contained in Section 3. Section 4 provides the empirical results, while the last section contains the concluding remarks and policy implications.

\section{Theoretical Framework and Empirical Issues}

Endogenous growth theory focuses on the dynamic gains accruable from trade liberalisation which became popular in mid-1980s. According to this approach, trade policy could impact on income and long-run growth through: scale effect; allocation effect; spill over effect and redundancy effect. The scale effect suggests that the common feature of the endogenous growth model is that the size of markets or scale of factor endowments affects directly the long-run growth rate. The integration of markets through trade could necessarily create scale effect through the integration of goods market or flows of intangible and non-rival knowledge capital. Allocation effect suggests that the gains from the reallocation of resources in neoclassical models could be sustained and transformed into the growth effect if the changes in the composition of national output are linked to the accumulable factors. An enhancement of growth can be sustained if more resources are allocated to the sector producing the accumulable factors. The relevance of the allocation theory to the less developed economies (LDCs), and in particular, to Nigeria, is made obvious because the rate of growth of LDCs will be clearly affected if the capital goods that embody technical contents that are so much required for the development of LDCs are subjected to tariff imposition.

With respect to spill-over effects, endogenous ggrowth theory shows that one important result of international trade is the diffusion and integration of technological knowledge. The result of this is access and exposure to the knowledge and technical goods obtained in other parts of the world. It has been observed that some knowledge is a non-rival good. The economy must necessarily be open for it to minimise the wastage generating from the use of the resources on Research and Development (R\&D) from the global perspective. When economies are exposed to the influence of competition from the outside world in the area of R\&D, redundancy can be eliminated in research across countries. The global resources devoted to R\&D will be efficiently utilised and the larger global stock of knowledge provides an extra boost to growth. It has been argued by scholars that in some models, the ultimate impact of trade policy depends crucially on the pattern of comparative advantage; especially in the area of R\&D-based growth models in which the long-run growth rate is determined by the extent of resources devoted to R\&D sector. In case the changes in prices cause the allocation of resources far away from the high-tech or innovative sector, trade liberalisation will produce a lower rate of growth.

Empirical Issues: Khor (2000) argued that a major problem that characterized trade liberalisation in less developed countries (LDCs) was the inability of the LDCs to determine by themselves, how fast their exports grow. LDCs could however control how fast to liberalise their imports and thereby increase the inflow of products. Khor argued that export promotion and performance which partly depended on the prices of the extant export prices and terms of trade, infrastructure, human capital development and enterprise capacity had deteriorated in LDCs. UNCTAD (1999) argued that the survival of LDCs in trade liberalisation depended on world market accessibility controlled and regulated by the developed countries who often imposed tariff and non-tariff barriers on exports of developing countries. Thus, protectionism from the developed economies (the North) had weakened the potential of LDCs to fully exploit existing and available comparative advantage. There has been a high incidence of wide inequalities among income groups within countries, which has been linked to globalisation. The UNCTAD's Trade and Development Report (1997) showed that 
since early 1980s inequality has characterised the world economy and North South income gaps have widened. In 1965, the average per capita income of the group of seven (G7) leading industrial countries was 20 times that of the world's poorest seven countries, by 1995, it had risen to 39 times as much. Even within countries, inequalities are noticeable. The income share of the richest 20 percent had risen since the early 1980s while the share of the 20 percent bottom had fallen significantly. The incomes of the poorest 25 percent now average less than one-tenth that of the richest 20 percent. The share of the middle class has also changed.

Nayaar (1997) examined the phenomenon of uneven development. He noted that globalisation has benefited the developed countries tremendously. More still, he noted that globalisation has benefited only a few developing countries. Thus the vast majority of developing countries remain largely detached from the benefits of globalisation. Nayaar further noted that only eleven developing countries which were an integral part of globalisation in the late $20^{\text {th }}$ century accounted for 66 percent of total exports from developing countries in 1992 (up from 30 percent of total exports from developing countries), 66 percent of annual FDI inflows to developing countries in 1981-1991; and most of portfolio investment flows to the developing world. Unfortunately, some of these countries have been severely affected by financial problem, debt overhang and economic problem. Thus the few benefits accruing to LDCs are further reduced. The level of development gap between the LDCs and developed economies is very wide and continues to widen with every passage of time. Khor (2000) attributed the above widening development gap to the following factors: unequal development of technology particularly information and communications technologies, dictatorships, abuse of power and economic mismanagement, excessive zeal for liberalisation despite lack of conducive conditions and preparedness and the fact that LDCs economics are not well organised within their own countries and at the international level to project their own agenda as they relate to globalisation. All these are coupled with poor regional institutions and groupings through which LDCs could better organise themselves, weaken the position of LDCs to project their image and voices at WTO, IMF and World Bank.

The trade openness/liberalisation engaged in by the LDCs has not favoured them remarkably. The LDCs export mainly primary commodities to the developed countries while they import manufactures from the developed world. This has been the pattern of trade in vogue since the colonial era and has continued till date. According to the Trade and Development Report, (1999); UNCTAD (1999), oil and non-oil primary commodity prices fell by 16.4 and 33.8 percent respectively from the end of 1996 to February 1999, resulting from a cumulative terms of trade loss of more than 4.5 percent of income during $1997-1998$ for developing countries. Rajan (2002) advanced the argument that the bulk of the countries that had made significant growth were those that integrated rapidly with the global economy in a market-consistent manner. Available evidence suggested also that it would be illogical to assume that trade liberalisation per se could generate trade and income growth and poverty reduction on a sustained basis. Rajan therefore suggested that trade liberalisation should be complemented with other policy measures to ensure the successful integration of a country with the world to generate rapid growth and poverty reduction.

Knight (2002) examined the impact of trade liberalisation on higher education policy implications. The identified fundamental implications emanating from education are: the use of information and communication technologies (ICTs) for domestic and cross border delivery of programmes; the growing number of private-for-profit entities providing higher education opportunities domestically and internationally; the increasing costs and tuition fees faced by students of public and private institutions. Additional implications are the need of public institution to seek alternate sources of funding which sometimes means engaging in for-profit activities or seeking private sector sources of financial support; and the ability or inability of government to fund the increasing demand for higher and adult education According to Miyamoto (2003), Multinational Enterprises (MNEs) could contribute to economic growth in the host developing countries by providing training and supporting formal education to the host countries. It was equally observed that the MNEs could contribute to technological transfers through numerous channels of training spillovers, involving vertical and horizontal linkages, labour turnovers and spin-offs. Host countries could enhance technology transfers through improvements in absorptive capacity of the host countries by consolidating their human capital development base. Soludo (2008) was also of the opinion that capital inflows especially FDI and remittances represent an important factors in achieving economic development. 
A couple of studies that address the impact of trade liberalisation on poverty have been carried out in Nigeria. Nwafor, Kanayo O. and Adenikinju (2005) examined the impact of trade liberalisation on poverty in Nigeria focusing on the effects of reduction of import tariffs on poverty and income distribution in Nigeria. He employed dynamic computable general equilibrium model along with the SAM based on 1997 imput-output and supply and use table (SUT) by theFOS. The study revealed that in the short term, the poverty in the rural area was more than that of the urban sector.He however concluded that in the long term the positive effect of tariff reduction was manifest. The finding of Nwafor et al of a positive effect of trade liberalisation on poverty in the long term contrasted with the position of Akinyosoye et al (1996). The latter observed that an appreciation of the Naira exchange rate encouraged imports and discouraged exports. Thus domestic prices would be depressed which created a destabilising effect on domestic prices. They showed that this effect is similar to that of tariff reduction. This position found support in the studies by Kuji (2002) and Olofin (2001). The study by Olofin (2001) based on 1999 SAM was aimed at examining the effect of a reduction in tariffs. The study showed that the net effect of tariffs reduction eventually depended on whether the household is a net consumer or producer of the products concerned.

\section{Methodology}

The variables were initially tested for stationarity most recent developments in macro because most macroeconomic time series data are not stationary in their levels and that many time series data are better adequately represented by first differences (Dickey, Jensen and Thornton, 1991). To examine the existence of unit root problem in the data series, two methods were used: Augmented Dickey Fuller (ADF) and the PhilipsPerronTests. Both tests are superior estimation techniques over other methods because they both control for higher order autocorrelation. The unit root test was followed by the determination of the order of the reduced form VAR by employing Akaike Information Criterion (AIC), Schwartz Bayesian Criterion (SBC), and Hannah-Quinn Criterion (HQ). The basis for selection of the appropriate lag length is identifying the criterion with the minimum lag length as the optimal lag length. This is followed by cointegration test using a multivariate approach proposed by Johansen (1988) and Johansen and Juselius (1990). This approach is based on two likelihood ratio test statistics (trace test and maximum eigenvalue test) applied to test the null hypothesis of at most ' $r$ ' cointegrating vectors among the variables.

Having done the initial estimations, if the variables are $I(1)$ but are not cointegrated, the next step is to estimate the reduced form VAR model as represented in equations 1 to 3 .

$$
\begin{aligned}
& T L_{1, t}=\alpha_{1}+\sum_{k=1}^{\alpha} \beta_{1, k} T L_{t-k}+\sum_{k=1}^{\alpha} \phi_{1, k} L M S_{t-k}+\sum_{k=1}^{\alpha} \rho_{1, k} \operatorname{INFLIRT}_{t-k}+\sum_{k=0}^{\alpha} \xi_{1, k} L R G D P_{t-k}+\sum_{k=0}^{\alpha} \delta_{1, k} L P O V_{t-k}
\end{aligned}
$$

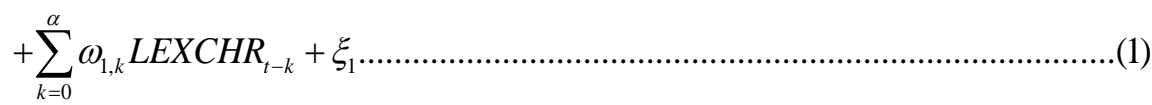

$$
\begin{aligned}
& L R G D P_{1, t}=\alpha_{2}+\sum_{k=1}^{\alpha} \beta_{1, k} T L_{t-k}+\sum_{k=1}^{\alpha} \phi_{1, k} L M S_{t-k}+\sum_{k=1}^{\alpha} \rho_{1, k} I_{N F L I R T} T_{t-k}+\sum_{k=0}^{\alpha} \xi_{1, k} L R G D P_{t-k}+\sum_{k=0}^{\alpha} \delta_{1, k} L P O V_{t-k}
\end{aligned}
$$

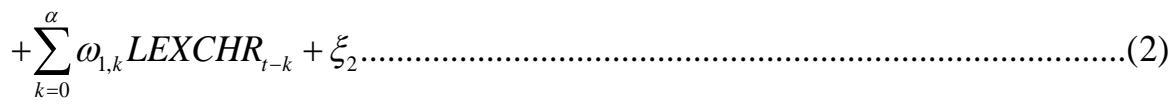

$$
\begin{aligned}
& L P O V_{1, t}=\alpha_{3}+\sum_{k=1}^{\alpha} \beta_{1, k} T L_{t-k}+\sum_{k=1}^{\alpha} \phi_{1, k} L M S_{t-k}+\sum_{k=1}^{\alpha} \rho_{1, k} \operatorname{INFLIRT}_{t-k}+\sum_{k=0}^{\alpha} \xi_{1, k} L R G D P_{t-k}+\sum_{k=0}^{\alpha} \delta_{1, k} L P O V_{t-k} \\
& +\sum_{k=0}^{\alpha} \omega_{1, k} L E X C H R_{t-k}+\xi_{3}
\end{aligned}
$$

Equations 1 to 3 are specified as Vector Autoregression (VAR) model that treats each endogenous variable as a function of the lags of itself and the lags of each of the remaining variables. Thus, three equations are specified to reflect the three endogenous variables i.e. trade liberalisation, poverty level and economic growth equations. If they are however I(1) and cointegrated, the approach is to estimate the vector error correction 
model (VECM) with proper cointegration (Gunduz, 2000). The alternative approach is the estimation of impulse response function and forecast variance decomposition from unrestricted VAR in levels. The need to determine optimal lag length is important. For instance, if there are $\mathrm{n}$ variables with lag length $\mathrm{k}$, it follows that $n(n k+1)$ coefficients will necessarily be estimated.Lag length is particularly relevant in that it is capable of influencing the power of rejecting hypothesis. A large and superfluous lag length is capable of wasting a lot of degree of freedom. On the other hand, when lag length that is too small is used, essential lag dependencies will be omitted from the VAR. This has significant adverse consequence in the presence of serial correlation capable of generating inconsistent estimates of the model.

The ordering of the variables determines the recursive causal structure of the VAR. This becomes necessary because altering the order unconditionally changes the relationship structure of the innovations. As the variables of interest are six, thus the model is a six dimensional model which involves six factorials arrangement giving a total of 720 different orders of endogenous variables. This further evoked the need for an optimal ordering pattern which is considerably guided by intuition. In some cases, policy variables are considered first before the non-policy variables in the ordering while in other cases, the study is guided by previous approaches in the literature. To ensure that the result of impulse response functions (IRFs) and Forecast Error Decomposition (FEVD) are not affected by variable ordering, sensitivity analysis were performed to determine how the structural analysis based on IRFs and FEVD are affected by causal ordering. The sensitivity analysis was based on estimating the VAR using variants of variable ordering. The recursive scheme above is just-identified and the astericks $\left({ }^{*}\right)$ imply freely estimated parameters.

Sources of data: The quarterly data on real gross domestic product, exchange rate, consumer price index degree of openness, money supply, external reserves and labour force participation rate employed were sourced from the International Financial Statistics (IFS) published by the International Monetary Fund (IMF), Central Bank of Nigeria Statistical Bulletin (various issues) and the National Bureau of Statistics (formerly Federal Office of Statistics ). This study adopts the Gandolfo's (1981) algorithm for the interpolation of annual real data series using quarterly flow series (Asogu, 1998). Interpolation technique is considered justified on the grounds that it is based on order statistical theory not confined to any variable type, whether stock or flow.

Definition and Measurements of Variables: The basic aim of this study is to examine the nexus existing among trade liberalisation, economic growth and poverty in the Nigerian economy over the sampled period of 1980 and 2009. A set of variables that directly relates to the above three compartments of the study was considered. The variables employed in this study are mainly macroeconomic variables. One of the variables is Real Gross Domestic Product (RGDP) which is defined as the nominal GDP deflated by the composite consumer price index. Money Supply is measured by broad money supply. There is however a scanty theoretical basis for selection of a monetary variable between narrow and broad money (Nwaobi, 1999). Some empirical stu dies have however confirmed the superiority of broad money (M2) over narrow money definition (M1) as a good monetary policy indicator in Nigeria (Nnanna, 2002; Sanusi, 2001; and Oyejide, 2002). Exchange Rate Variable: Exchange rate variable is captured by the Nigeria's nominal effective exchange rate and is measured by Naira to Dollar rate. Trade Liberalisation is proxied by openness and trade liberalization Index. Opennessis is measured in two ways: i.e policy and outcome measures (Saibu, 2004). There are however arguments about the superiority of one over the other in the literature (Akinlo, 2003 and Rodrick, 2000) .Openness, a proxy for trade liberalisation in this study, is estimated from the output perspective for two reasons: first, there is no continuous long time series data on most of policy measures such as effective tariff rates on imports and exports. Second, a critical weakness of any measure based on tariffs is that the typical trade regime of developing countries restricts imports with other barriers. For many products, the tariffs are considerably redundant, thus they do not provide any additional protection for domestic producers. Thus the unavailability of time series data on tariffs might not provide a valid indicator for trade liberalisation; hence the choice of openness variable which proxies trade liberalisation.

Another proxy for trade liberalisation is the trade liberalisation index which is represented as a dummy variable that takes the value of one for every year or quarter when there was trade liberalisation and zero elsewhere when there was no trade liberalisation in Nigeria. Poverty variables include the following: Life 595 
expectancy variable (Lifes) which depicts the general health status is proxied as life expectancy (in years) per 1000 live births. The poverty, proxied as the level of employment, is defined as the labour force participation rate. The use of this proxy is informed by paucity of official employment data in Nigeria. Another Poverty indicator employed in the study is real consumption expenditure per capita following previous studies by Ogun (2010) and Okojie (2002). The two studies employed real consumption expenditure as an alternative to per capita income on the basis of consensus in the literature that an expenditure measure of poverty is superior to income measures.

\section{Results}

Time Series Properties of the Data: In line with the usual practice in macroeconomic studies, data are examined for unit root problem using Augmented Dickey Fuller (ADF) and Philips and Perron (PP) tests. These results are presented below:

Table1: UNIT ROOT TEST FOR QUARTERLY DATA SERIES

\begin{tabular}{|c|c|c|c|c|c|c|c|}
\hline \multirow[b]{2}{*}{ Variable } & \multicolumn{6}{|c|}{ Unit root tests } & $\begin{array}{l}\text { Degree } \\
\text { of } \\
\text { Integration }\end{array}$ \\
\hline & Levels & 1st Diff. & 2nd.Diff. & Levels & 1st Diff. & 2nd Diff. & $\begin{array}{ll}\text { (PP } & \text { and } \\
\text { ADF) }\end{array}$ \\
\hline $\begin{array}{l}\text { With Intercept } \\
\text { only }\end{array}$ & & & & & & & \\
\hline LEXCHR & -1.456 & $-4.872^{* *}$ & $-7.970^{* *}$ & -1.256 & $12.066^{* *}$ & $-30.231^{* *}$ & $\mathrm{I}(1)$ \\
\hline LLABFPR & -2.33 & $-3.601^{* *}$ & $-8.094^{* *}$ & -1.102 & $-4.480^{* *}$ & $-15.475^{* *}$ & $\mathrm{I}(1)$ \\
\hline LMS & 0.05 & $-4.787^{* *}$ & $-7.900^{* *}$ & 0.211 & $-10.010^{* *}$ & $-23.197 * *$ & $\mathrm{I}(1)$ \\
\hline LOPN & -1.161 & $-5.259 * *$ & $-6.865^{* *}$ & -0.436 & $-8.735^{* *}$ & $-20.459^{* *}$ & $\mathrm{I}(1)$ \\
\hline LRGDP & 0.252 & $-8.618^{* *}$ & $-6.895^{* *}$ & -3.588 & $-10.693^{* *}$ & $-23.536^{* *}$ & $\mathrm{I}(1)$ \\
\hline LRPCEC & -0.964 & $-8.016^{* *}$ & $-7.257^{* *}$ & $-4.304^{* *}$ & $-10.869^{* *}$ & $-23.628^{* *}$ & $\mathrm{I}(1)$ \\
\hline TDLIND & -2.169 & $-4.775^{* *}$ & $-8.013^{* *}$ & 2.012 & $-10.863^{* *}$ & $-26.763^{* *}$ & $\mathrm{I}(1)$ \\
\hline INFLRT & -2.716 & $-4.800^{* *}$ & $-7.517^{* *}$ & $-2.648^{* *}$ & $-6.914^{* *}$ & $-17.685^{* *}$ & $\mathrm{I}(1)$ \\
\hline $\begin{array}{l}\text { With Intercept } \\
\text { and Trend }\end{array}$ & & & & & & & \\
\hline LEXCHR & -1.493 & $-5.022^{* *}$ & $-7.932 * *$ & -1.544 & $-12.112^{* *}$ & $-30.085^{* *}$ & $\mathrm{I}(1)$ \\
\hline LLABFPR & -1.287 & $-4.224^{* *}$ & $-8.230^{* *}$ & -1.102 & $-4.478^{* *}$ & $-15.557^{* *}$ & $\mathrm{I}(1)$ \\
\hline LMS & -3.167 & $-4.822^{* *}$ & $-7.865^{* *}$ & -2.84 & $-10.005^{* *}$ & $-23.070^{* *}$ & $\mathrm{I}(1)$ \\
\hline LOPN & -1.864 & $-5.121^{* *}$ & $-6.947^{* *}$ & $-3.702^{* *}$ & $-8.742^{* *}$ & $-20.405^{* *}$ & $\mathrm{I}(1)$ \\
\hline LRGDP & $3.145^{* *}$ & $-8.506^{* *}$ & $-7.083^{* *}$ & $-5.392^{* *}$ & $-10.760^{* *}$ & -23.405 & $\mathrm{I}(0)$ \\
\hline LRPCEC & -3.528 & $-7.803^{* *}$ & $-7.547^{* *}$ & $-5.216^{* *}$ & $-10.886^{* *}$ & $-23.577^{* *}$ & $\mathrm{I}(1)$ \\
\hline TDLIND & -1.839 & $-4.941^{* *}$ & $-7.976^{* *}$ & -1.782 & $-10.930^{* *}$ & $-26.625^{* *}$ & $\mathrm{I}(1)$ \\
\hline INFLRT & -2.839 & $-4.775^{* *}$ & $-7.481^{* *}$ & -3.071 & $-7.364^{* *}$ & $-17.604^{* *}$ & $\mathrm{I}(1)$ \\
\hline
\end{tabular}

Critical Values: 1.00 Per cent: -3.593; 5.00 per cent:-2.932. Note: LEXCHR, LLABFPR, LMS, LOPN, LRGDP, LRPCEC, TLINDEX and INFLRT are log of exchange rate, log of labour force participation rate, log of money supply, log of openness, log of real gross domestic product, log of real per capita expenditure on consumption, trade liberalisation index and inflation rate respectively. ADF stands for augmented dickey fuller test, while PP stands for Philip and Perron test. The null hypothesis(Ho) is that there is a unit root process. It could be 
inferred from the results presented in Table 1 that all the variables are stationary at first difference; that is, they are integrated of order one $(I(1))$..

Cointegration Test: The results of unrestricted cointegrated rank tests for quarterly time series used were presented in Table 2. The need to verify the existence of at least one linear long run relationship among the variables of interest that are integrated of the same order, in this case order one, becomes imperative. The test was done for each of the model variables. The results are presented below:

Table 2: Unrestricted Cointegration Rank Test (Trace) for Quarterly Data

\begin{tabular}{lcccc}
\hline Model 1: & \multicolumn{5}{c}{ Series: LEXCHR LOPN LMS INFLRT LRGDP LRPCEC } \\
Hypothesised & Eigenvalue & Trace & $\mathbf{0 . 0 5}$ Critical & Prob** $^{* *}$ \\
\hline No of Ces & 0.447 & 166.663 & 95.754 & 0.000 \\
None ${ }^{*}$ & 0.329 & 97.426 & 69.819 & 0.000 \\
At most $1 *$ & 0.182 & 50.840 & 47.856 & 0.026 \\
At most 2 & 0.141 & 27.369 & 29.797 & 0.093 \\
At most 3 & 0.070 & 9.648 & 15.495 & 0.309 \\
At most 4 & 0.010 & 1.118 & 3.842 & 0.290 \\
At most 5 & Statistic & Value \\
Trace test indicates 3 cointegratingeqn(s) at the 0.05 level \\
* denotes rejection of the hypothesis at the 0.05 level \\
** MacKinnon-Haug-Michelis (1999) p-values \\
\hline
\end{tabular}

Model 2

Series: LEXCHR LOPN LMS INFLRT LRGDP LLABFPR

$\begin{array}{lllll}\begin{array}{l}\text { Hypothesised } \\ \text { No of Ces }\end{array} & \text { Eigenvalue } & \begin{array}{l}\text { Trace } \\ \text { Statistic }\end{array} & \begin{array}{l}0.05 \text { Critical } \\ \text { Value }\end{array} & \text { Prob }^{* *} \\ \text { None } & & 146.450 & 95.754 & 0.000 \\ \text { At most } 1 * & 0.408 & 85.132 & 69.819 & 0.002 \\ \text { At most } 2 * & 0.265 & 49.041 & 47.856 & 0.039 \\ \text { At most 3 } & 0.175 & 26.571 & 29.797 & 0.113 \\ \text { At most 4 } & 0.123 & 11.235 & 15.495 & 0.198 \\ \text { At most 5 } & 0.072 & 2.526 & 3.841 & 0.112\end{array}$

Trace test indicates 3 cointegrating eqn(s) at the 0.05 level

$*$ denotes rejection of the hypothesis at the 0.05 level

**MacKinnon-Haug-Michelis (1999) p-values

Model 3

Hypothesised

No of Ces

None *

At most 1

At most 2

At most 3

At most 4

At most 5
Series: LEXCHR TRDLIND LMS INFLRT LRGDPLLABFPR

$\begin{array}{llll}\text { Eigenvalue } & \text { Trace } & 0.05 \text { Critical } & \text { Prob }^{* *} \\ & \text { Statistic } & \text { Value } & \\ 0.408 & 124.995 & 95.754 & 0.000 \\ 0.216 & 63.700 & 69.819 & 0.140 \\ 0.121 & 35.302 & 47.856 & 0.432 \\ 0.101 & 20.234 & 29.797 & 0.407 \\ 0.051 & 7.809 & 15.495 & 0.486 \\ 0.015 & 1.719 & 3.842 & 0.190\end{array}$


Trace test indicates 1 cointegrating eqn(s) at the 0.05 level

* denotes rejection of the hypothesis at the 0.05 level

**MacKinnon-Haug-Michelis (1999) p-values

Model 4

Series: LEXCHR TRDLIND LMS INFLRT LRGDPLLABFPR

Hypothesised

Eigenvalue

Trace

0.05 Critical

Prob**

No of Ces

None *

0.451

Statistic

Value

At most $1^{*}$

0.357

162.188

95.754

0.000

At most 2

0.169

91.958

69.819

0.000

At most 3

0.085

40.229

47.856

0.214

At most 4

0.059

18.564

29.797

0.525

At most 5

0.009

8.159

15.495

0.449

1.022

3.842

0.312

Trace test indicates 2 cointegratingeqn(s) at the 0.05 level

* denotes rejection of the hypothesis at the 0.05 level

**MacKinnon-Haug-Michelis (1999) p-values

From table 8, the results of the cointegration test for the variables contained in model i.e. LEXCHR LOPN LMS INFLRT LRGDP LRPCEC shows an evidence of at least 3 cointegrated relations among the variables. Also, model 2, with the following variables: LEXCHR LOPN LMS INFLRT LRGDP LLABFPRshows evidence of the presence of at least 3 cointegrated relations among the variables. Model 3 however shows that the variables contained in the model i.e. LEXCHR TRDLIND LMS INFLRT LRGDPLLABFPR had at least one cointegrated relation. Model 4 on its part showed that the variables in the model i.e.: LEXCHR TRDLIND LMS INFLRT LRGDPLLABFPR had at least 2 cointegrated relations. Overall, for the variables contained in each of the models, at least one cointegrating relations ${ }^{1}$ could be established among the model variables. However, the fact that there are long run relationships among the variables does not suggest the existence of any pattern of relations among the variables. To establish this pattern, the analysis of both short run multivariate causal interactions among the variables in a vector-autoregression model and the impulse response function (IRF) as well as the variance decomposition generated were carried out.

Test Statistics and Choice of Criteria for Selecting the Order of VAR Model: As four VAR models were estimated, the lag length order search was of four variants. The endogenous variables orderings entered the four structural VAR models the same way. What is different in each case is that the endogenous variables of interest for measurement replaced those variables that were no longer needed in the VAR model of interest. This is in line with equations 1 to 3 . Table 3 in the appendix depicts the various test statistics used to determine the optimal lag length for the variants of unrestricted VAR models. In panel 1, the Akaike information criteria (AIC) indicates an optimal lag length of 12. The Schwarz information criteria (SIC) shows a lag length of 1 while the Hannah-Quinn information (HQ) depicts an optimal lag length of 5. In panel 2, AIC shows optimal lag length of 12 while SIC and HQ imply optimal lag lengths of 1 and 9 respectively. In Panel 3 , AIC gives the optimal lag lengths of 8, while those of SC and HQ are 1 and 4 respectively. The last VAR model (3) shows optimal lag length using AIC as 7 while SC and HQ optimal lag values are 1 and 4 respectively. It is so obvious that the results from this optimal lag length selection using these three methods are contradictory. A way to overcome this in the literature is to choose the SC criterion as it has a relatively better performance in lag choice accuracy than the other selection methods in majority of the cases (See Hacker and Hatemi,

1 On the basis of the existence of at least one cointegrating relation among the variables suggesting cointegrated variables, Error Correction (EC) Term was incorporated into the VAR model before estimation. To maintain consistency, VAR with EC, henceforth called VAR was employed rather than the term Vector Error Correction model (VECM). 
2008). It is therefore selected as the most efficient and reliable criterion. Besides, the Schwarz information criterion (SC) is generally more conservative in terms of lag length than the Akaike Information criteria (AIC).

Robustness tests of the Residuals: Having determined the lag length, the next approach is to examine whether the chosen VARs have the appropriate properties. Thus, the following tests were carried out: normality and autocorrelated tests and the stability test. The various tests were carried out for each of the VAR models i.e. models 1 to 3.

Figure 1: The inverse Roots of AR Characteristic Polynomial of VAR Model $1^{2}$

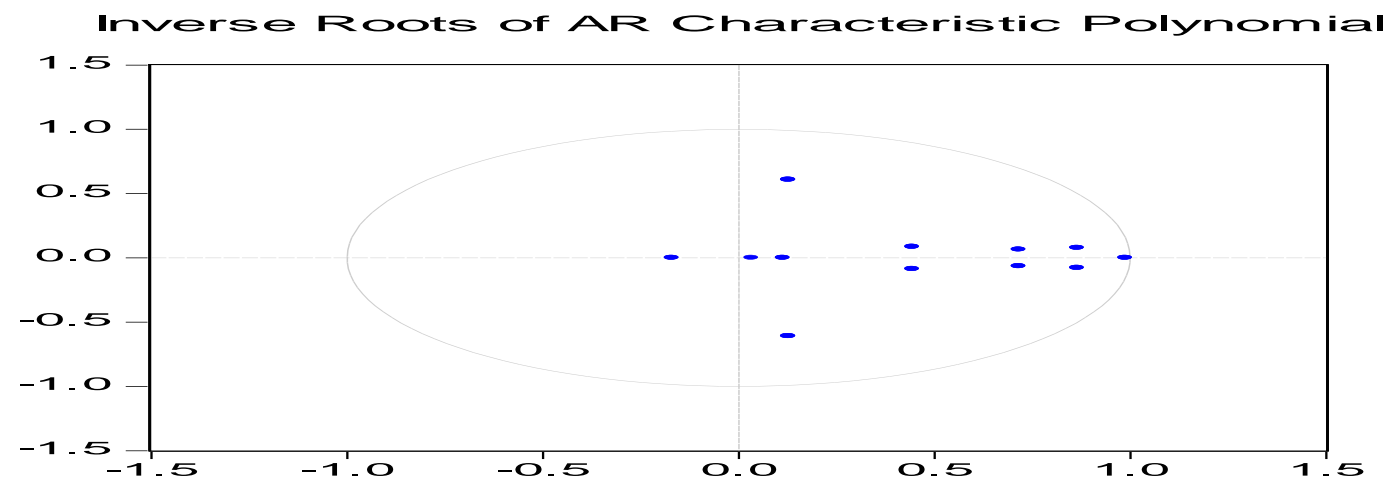

The VAR stability test became necessary because the focus was to obtain Vector Moving Average (VMA) from the VAR. This demands the stability of VAR. The results presented in figures 12 to 15 imply that the VAR model 1, model 2, model 3 and model 4 are stable as all the roots of each of the models lie within the unit circles. This is confirmed by the table of the Roots of Characteristic Polynomial presented in the Appendix (table A.8 to A.11). This finding shows that the VARs satisfy the stability conditions. The VAR Residual Serial Correlation LM tests were carried out for each of the four models under the null hypothesis that there is no serial correlation at lag order $\mathrm{h}^{3}$. It is observed that in most of the lag lengths, the maintained hypothesis of no serial correlation was not rejected for all the models.

Impulse Response Function Analysis for model 1: The result of impulse response for model one is presented in table 10. The table shows the responses of openness variable (LOPN) to other variables in the model, Real GDP to other model variables and the Per capita Expenditure on Consumption (LRPCEC) to other model variables. For the purpose of easy analysis, the estimates of the variables measured in logs approximate the percentage change of those variables in response to a one standard deviation shock in each of the endogenous variable's innovations.

Table 3: VAR Impulse Response Analysis (Model 1 1) $^{4}$

2 The results of models 2, 3, and 4 are similar to the one presented in figure 12 for model 1 . Thus they are not reported as they are constructed as a robustness check to confirm our results

${ }^{3}$ The tests of VAR Residual Serial Correlation LM tests were carried out for each of the four models but the results are not presented in the paper

${ }^{4}$ The results of models 2,3 and 4 are not presented as they follow the same pattern as presented in table 10. 


\begin{tabular}{|c|c|c|c|c|c|c|}
\hline \multicolumn{7}{|c|}{ Response of LOPN to: } \\
\hline (Quarters) & LEXCHR & LOPN & LMS & INFLRT & LRGDP & LRPCEC \\
\hline \multirow[t]{2}{*}{1} & 0.025 & 0.231 & 0.000 & 0.000 & 0.000 & 0.000 \\
\hline & $(0.021)$ & $(0.015)$ & $(0.000)$ & $(0.000)$ & $(0.000)$ & $(0.000)$ \\
\hline \multirow[t]{2}{*}{4} & 0.071 & 0.154 & -0.025 & 0.035 & 0.088 & 0.007 \\
\hline & $(0.028)$ & $(0.032)$ & $(0.032)$ & $(0.032)$ & $(0.030)$ & $(0.033)$ \\
\hline \multirow[t]{2}{*}{8} & 0.119 & 0.073 & -0.005 & 0.041 & 0.055 & -0.027 \\
\hline & $(0.033)$ & $(0.033)$ & $(0.041)$ & $(0.039)$ & $(0.034)$ & $(0.023)$ \\
\hline \multirow[t]{2}{*}{12} & 0.145 & 0.024 & -0.012 & 0.011 & 0.029 & -0.033 \\
\hline & $(0.039)$ & $(0.033)$ & $(0.041)$ & $(0.039)$ & $(0.033)$ & $(0.020)$ \\
\hline \multirow[t]{2}{*}{16} & 0.150 & -0.001 & -0.023 & -0.016 & 0.018 & -0.033 \\
\hline & $(0.043$ & $(0.033)$ & $(0.042)$ & $(0.038)$ & $(0.033)$ & $(0.021)$ \\
\hline \multirow[t]{2}{*}{20} & 0.146 & -0.010 & -0.028 & -0.029 & 0.016 & -0.031 \\
\hline & $(0.046)$ & $(0.034)$ & $(0.044)$ & $(0.038)$ & $(0.034)$ & $(0.021)$ \\
\hline \multirow[t]{2}{*}{24} & 0.137 & -0.012 & -0.029 & -0.034 & 0.017 & -0.029 \\
\hline & $(0.048)$ & $(0.034)$ & $(0.046)$ & $(0.038)$ & $(0.034)$ & $(0.020)$ \\
\hline \multicolumn{7}{|c|}{ Response of LRGDP to: } \\
\hline (Quarters) & LEXCHR & LOPN & LMS & INFLRT & LRGDP & LRPCEC \\
\hline \multirow[t]{2}{*}{1} & $\begin{array}{l}6.96 \mathrm{E}- \\
05\end{array}$ & -0.122 & -0.001 & 0.004 & 0.105 & 0.000 \\
\hline & $(0.015)$ & $(0.012)$ & $(0.009)$ & $(0.009)$ & $(0.007)$ & $(0.000)$ \\
\hline \multirow[t]{2}{*}{4} & 0.001 & -0.025 & 0.014 & -0.002 & 0.029 & -0.036 \\
\hline & $(0.012)$ & $(0.015)$ & $(0.016)$ & $(0.016)$ & $(0.015)$ & $(0.017)$ \\
\hline \multirow[t]{2}{*}{8} & 0.002 & -0.001 & 0.014 & -0.003 & 0.015 & -0.009 \\
\hline & $(0.011)$ & $(0.010)$ & $(0.013)$ & $(0.013)$ & $(0.010)$ & $(0.005)$ \\
\hline \multirow[t]{2}{*}{12} & 0.008 & 0.008 & 0.009 & 0.001 & 0.013 & -0.005 \\
\hline & $(0.010)$ & $(0.007)$ & $(0.009)$ & $(0.009)$ & $(0.007)$ & $(0.003)$ \\
\hline \multirow[t]{2}{*}{16} & 0.014 & 0.009 & 0.006 & 0.002 & 0.011 & -0.005 \\
\hline & $(0.009)$ & $(0.006)$ & $(0.008)$ & $(0.006)$ & $(0.006)$ & $(0.003)$ \\
\hline \multirow[t]{2}{*}{20} & 0.019 & 0.007 & 0.003 & 0.001 & 0.009 & -0.005 \\
\hline & $(0.008)$ & $(0.006)$ & $(0.007)$ & $(0.006)$ & $(0.005)$ & $(0.003)$ \\
\hline \multirow[t]{2}{*}{24} & 0.022 & 0.004 & 0.000 & -0.000 & 0.007 & -0.006 \\
\hline & $(0.008)$ & $(0.006)$ & $(0.007)$ & $(0.006)$ & $(0.005)$ & $(0.003)$ \\
\hline \multicolumn{7}{|c|}{ Response of LRPCEC to: } \\
\hline (Quarters) & LEXCHR & LOPN & LMS & INFLRT & LRGDP & LRPCEC \\
\hline \multirow[t]{2}{*}{1} & -0.006 & -0.129 & -0.000 & 0.004 & 0.101 & 0.040 \\
\hline & $(0.016)$ & $(0.013)$ & $(0.010)$ & $(0.010)$ & $(0.008)$ & $(0.003)$ \\
\hline \multirow[t]{2}{*}{4} & -0.006 & -0.023 & 0.011 & 0.002 & 0.020 & -0.037 \\
\hline & $(0.011)$ & $(0.015)$ & $(0.016)$ & $(0.015)$ & $(0.015)$ & $(0.017)$ \\
\hline \multirow[t]{3}{*}{8} & -0.006 & -0.002 & 0.013 & -0.002 & 0.009 & -0.008 \\
\hline & $(0.010)$ & $(0.009)$ & $(0.012)$ & $(0.012)$ & $(0.009)$ & $(0.006)$ \\
\hline & & & & 600 & & \\
\hline
\end{tabular}




\begin{tabular}{lllllll}
12 & -0.002 & 0.006 & 0.009 & 0.001 & 0.008 & -0.002 \\
& $(0.009)$ & $(0.006)$ & $(0.008)$ & $(0.008)$ & $(0.006)$ & $(0.002)$ \\
16 & 0.002 & 0.007 & 0.006 & 0.003 & 0.007 & -0.002 \\
& $(0.008)$ & $(0.005)$ & $(0.006)$ & $(0.005)$ & $(0.005)$ & $(0.002)$ \\
20 & 0.006 & 0.006 & 0.004 & 0.003 & 0.006 & -0.002 \\
& $(0.006)$ & $(0.005)$ & $(0.005)$ & $(0.005)$ & $(0.004)$ & $(0.002)$ \\
24 & 0.009 & 0.004 & 0.002 & 0.001 & 0.004 & -0.003 \\
& $(0.005)$ & $(0.004)$ & $(0.004)$ & $(0.004)$ & $(0.003)$ & $(0.002)$ \\
\hline
\end{tabular}

From the results of model 1 , a shock to exchange rate variable produced a positive response throughout the time horizon of 24 quarters. The estimate started from the low value of 0.03 in quarter 1 and increased gradually to 0.15 in quarter 16 and thereafter marginally declined to 0.14 in quarter 24 . This result implied that a shock to exchange rate that resulted in Naira appreciation would generate positive response from openness variable. A shock to openness (LOPN) would produce a strong positive effect on actual LOPN in the short and medium runs. The value of the estimate initially was 0.23 per cent in the first quarter. The positive sign of this variable was retained until $16^{\text {th }}$ quarter when the value became 0.02 per cent. At the beginning of $16^{\text {th }}$ quarter, the values were negative and became sustained till the end of the time horizon. Thus, given all other endogenous factors in the model, openness could be expansionary in the short and medium runs while being contractionary in the long run. A shock to money supply on its part had contractionary impact on openness in almost all the time horizon save in period one when the magnitude was zero. A shock to the innovation of inflation would have an expansionary impact on openness in the short and medium runs starting from 0.00 per cent to 0.01 per cent in quarter 12 . The trend however assumed negative value as from quarter 16 and remained persistent till the end of the period. This appeared to signal the importance of inflation targeting as a useful devise for sustaining the long run increase in openness in the Nigerian economy.

A shock to economic growth (LRGDP) variable whose graph is represented in row 2 column 5 shows a positive response throughout the periods. The figure attained zero value $(0.00)$ in $1^{\text {st }}$ quarter and progressively increased to 0.017 in $24^{\text {th }}$ quarter. The implication of this is that there is a strong link between the output growth and the degree of openness in the Nigerian economy. The positive reactions from openness appear to connote that for sustenance of the benefits derived from trade liberalisation, appropriate sequencing of output growth as a pre-condition for trade liberalisation is a sine qua non for reaping the optimal benefits of trade liberalisation. This in line with the arguments of Rodrick (2000) and Harsch (2006) about the middle-income countries like China and India which first secured a solid foundation for economic growth before liberalising trade. However, the low values of the estimates are an indication that the influence of output growth on trade liberalisation is still very insignificant in the Nigerian economy. A shock to real per capita expenditure on consumption (LRPCEC) that proxied poverty level in the VAR model produced an expansionary response on the openness variable in the short run i.e. between period 1 to period 4 . The trend was however reversed to negative as from period $8^{\text {th }}$ till the end of the time horizon in $24^{\text {th }}$ quarter. It needs be noted that the magnitudes of the short run positive values attained initially were substantially very low. They ranged between 0.00 in quarter 1 to 0.007 in quarter 4. It thus appears on the whole that a shock to the poverty variable of LRPCEC would produce negative impact in the long run and at best generate approximately zero effect on openness in the short run.

The response of real gross domestic product to a shock to exchange rate (i.e Naira to Dollar rate) generated positive responses throughout the entire time horizon. This suggests that foreign exchange appreciation promoted economic growth. The shock to openness however induced a mixture of contractionary and expansionary effects. Negative reactions were experienced between quarters 1 and 8 . Thereafter, the pattern became positive till the end of the period. This appears to suggest that openness impact on output growth is mixed. The impact is contractionary in the short run but expansionary in the long run. This gave an indication that to derive maximum benefits from trade liberalisation, Nigerians should be prepared to bear some initial 
side effects associated with its implementation. The shock to money supply (LMS) led to contractionary impact in quarter 1 but positive responses throughout the remaining time horizons. This appeared to follow the monetarist approach to achieve output growth in the economy. The coefficient values were however very varing between 0.00 and 0.02 low. The shock to inflation rate generated low responses from the log of real GDP varying between 0.00 and 0.01 . The shock to LMS induced a blend of positive and negative effects. A shock to Real GDP generated positive effects on the actual Real GDP throughout the 24 quarters. The reaction initially produced a significant effect but the magnitude rapidly decreased to 0.00 in quarter 24 . The shock to real per capita expenditure on consumption (LRPCEC) produced contractionary effect on Real GDP for almost all the time horizon. Quarter 1 was the only period without a negative value. Overall, the shock to LPCEC generated contractionary impact on the general output level in the economy. Furthermore, the real per capita expenditure on consumption (LRPCEC)responses to endogenous shock to exchange rate (LEXCHR) produced contractionary effects in the short run and in the medium run up to $12^{\text {th }}$ quarters. LEXCHR exerted positive and expansionary impacts on consumption pattern between 12 and 24 quarters. In similar fashion, the log of openness exerted a contractionary impact on LRPCEC for periods between $1^{\text {st }}$ and $8^{\text {th }}$ quarters. From quarter $12^{\text {th }}$ to $24^{\text {th }}$, the impact of LOPN on LRPCEC became expansionary. This implies that the effect of trade liberalisation on LRPCEC could vary from negative effect in the short run to positive effect in the long run.

The shock to Money Supply (LMS) led to contraction on LRPCEC in quarter one but became expansionary for the remaining part of the time horizon. This again supported the position of the monetarists related to appropriate strategy to achieve the growth of the economy and welfare enhancement. Also shocks to inflation rate caused LRPCEC to be expansionary. It was only in quarter $8^{\text {th }}$ that the response of LRPCEC became contractionary. Thereafter, the response of LRPCEC became expansionary. This tends to support the theoretical position in the literature that some level of inflation is desirable in an economy to enhance productive sector activities and, through multiplier effect, this enhances the level of consumption expenditure of the economic agents. A shock to the LRGDP variable generated positive effect on LRPCE throughout the entire time horizon. The effect was significantly pronounced up till $4^{\text {th }}$ quarter, but became marginal for the remaining part of the time horizon. This again confirms the important role of output growth in enhancing the consumption expenditure. The pattern of the shock to real per capita expenditure on consumption (LRPCEC) produced counter-intuitive contractionary effect in the entire time horizon except the $1^{\text {st }}$ quarter. The possible explanation could be that economic policies such as monetary and fiscal policies led to skewed income distribution pattern with adverse affect on the consumption pattern of the populace.

Results of Forecast Error Variance Decomposition (FEVD) based on the specified models: The result in the preceding section indicates that achieving a sound economic growth is a crucial pre-condition to achieving success in trade liberalisation and in combating the menace of poverty in Nigeria. In order to further espouse the link among the trade liberalisation, economic growth and poverty, the variance decomposition derived from the VAR was generated and analysed. This is a decomposition of forecast error in an endogenous variable into the component shocks of the endogenous variables in each of the considered models. According to Akinlo (2003), while impulse response functions are very useful in ascertaining the direction of the effect of a shock to innovations of a variable, the magnitude of the effect of the shock to the innovation can only be deciphered by Forecast Error Variance Decompositions; in other words, they show the explanatory contribution of the shock to the innovations of the variables. They indicate the proportion of the forecast error in a given variable that is accounted for by innovations in each endogenous variable.

Empirical Results of Model 1: Model 1 comprises the following variables: LEXCHR, LOPN, LMS, INFLIRT, LRGDP and LRPCEC. The results presented in the first panel in table 14 show that the own shocks explained a large proportion of the variations in the variance of openness (LOPN). The magnitude however decreased from a high value of 99 per cent to 80 per cent. Other variables that are of importance are exchange rate (LEXCHR) and real gdp (LRGDP). LEXCHR increased progressively from low value of 1.2 to 55.5 per cent while LRGDP increased from 0.00 per cent to 11.5 in quarter 8 and marginally decreased to 6.6 per cent in quarter 24 . When this result is combined with that of impulse response it largely confirmed the positive impact of real output growth (LRGDP) on openness which proxied trade liberalisation. The second panel in table 14 depicts the proportions of forecast error variance in LRGDP explained by innovations of the considered endogenous variables. The three variables that appeared crucial in determining the variation in 
the variance of LRGDP are LOPN, LRGDP and LRPCEC.The magnitude of LOPN varied between 58 per cent in the first quarter and 49 per cent in the 24 quarter. The LRGDP varied between 36 per cent in quarter 1 and 33 per cent in quarter 24 while LRPCEC varied between 6 per cent and 13 per cent. When these results are considered along with the impulse response results, the importance of LOPN appeared mixed. The negative effect in the short run appeared to offset the positive effects in the long run. The influence of LOPN on LRGDP could therefore at best be considered neutral. The own short significantly influenced the variations in LRGDP. However, the real per capita expenditure on consumption (LRPCEC) could not be presumed to influence positively the LRGDP as the negative signs generated by impulse response negated this position.

\section{Figure 2: The Forecast Error Variance Decomposition (Model 1) ${ }^{5}$}
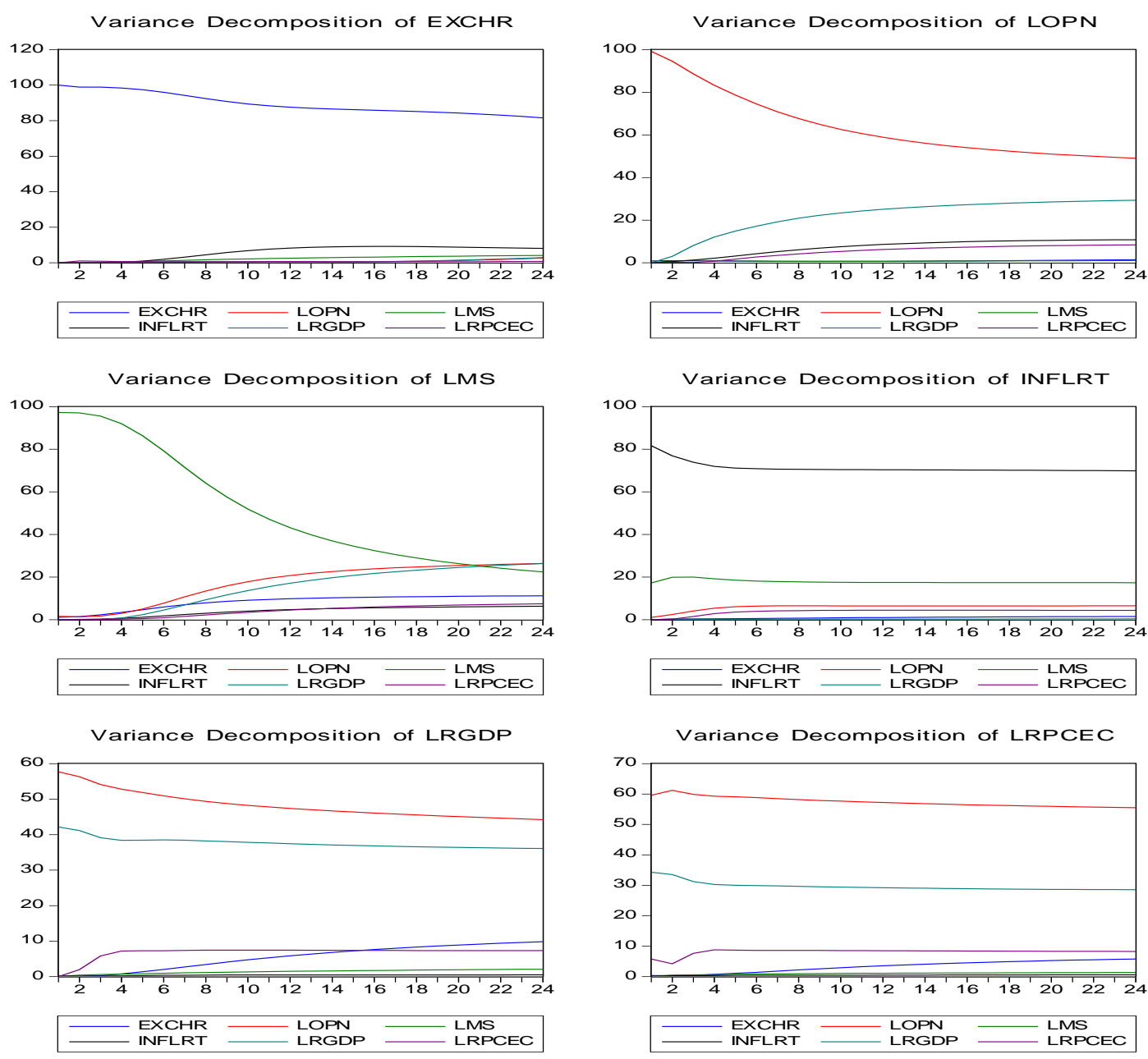

The last panel in table 14 shows the proportions of the forecast error variance in LRPCEC accounted for by LRPCEC and other endogenous variables. The variables that appeared to be important are LOPN, LRGDP and LRPCEC in that order. The trade liberalisation (LOPN) accounted for between 58 in quarter 1 to 42 per cent in quarter 24. This magnitude is rather very high. However, the fact that the impulse response showed negative signs up till quarter 8 largely weakened the contribution of LOPN. In sum, at best, the contribution of LOPN

5 The pattern of the graphs of variance decomposition for models 2,3 , and 4 are similar to that of model 1 , hence their results were not presented. The analyses for models 2,3 , and 4 were carried out as a robustness check to examine the sensitivity of our preferred model 1 to the use of other proxies to represent trade liberalisation, and poverty level. 
was neutral or rather mixed. Also, the contribution of LRPCEC was weakened by the fact that the impulse response showed LRPCEC with negative signs throughout the time horizon. It was only the own shock whose impulse response function and variance decomposition are consistent with a priori expectation, indicating the importance of own shock in contributing to LRGDP.

\section{Conclusion and Policy Implications}

Overall, the interactions among trade liberalisation, economic growth and poverty level showed that economic growth had a positive impact on trade liberalisation in Nigeria within the study period. Thus economic growth could serve as a policy variable for the purpose of achieving ultimate reduction of poverty level and positioning the Nigerian economy to derive maximum benefits from trade liberalisation. Furthermore, the results of impulse response analysis portray weak interactions among trade liberalisation, economic growth and poverty level. This largely indicates the presence of some structural rigidities in the economy that could prevent the full realization of the impact of trade liberalisation on poverty, particularly through economic growth channel. This suggests the presence of some institutional factors that create inherent problems in the economy capable of frustrating any valid and sincere trade policies formulated by the government. This largely explains the persistence of high poverty level in Nigeria. The policy implication derived from the findings suggest that in formulating trade policies, and poverty alleviation strategies, all attempts must be made to ensure that the domestic economy is well guided and structured to avoid the effects any structural rigidities that could adversely affect the output growth in the economy, particularly the purchasing power of the citizens that requires augmentation in the short run. Also, the policy makers should be mindful of the structural vulnerability of the Nigerian economy. They should be well informed that for any policy to succeed, the peculiar characteristics of the economy must be carefully considered and factored into any policy menu for good policy effects. In addition, it should be noted that any trade policy and poverty policy not complemented with sound economic growth policy has high propensity to fail.

\section{References}

Akinlo, A. E. (2003). Foreign direct investment and economics growth in sub-Saharan Africa. International Review of Economics and Business (RISEC), 50(4), 569-580.

Akinyosoye, V. O., Akande, S. O., Akpokodje, G. \& Mbanefoh, N. M. (1996). Trade and Exchange Rate liberalisation and Competitive Nigeria's Tradeable Commodities. NISER, Ibadan, NG 1996-04-01.

Asogu, J. O. (1998). The Relative Potency of Monetary and Fiscal Policies in Nigeria. Central Bank of Nigeria Economic and Financial Review, 36(2).

Bhagwati, J. (2001). Growth, Poverty and Reforms. Economic and Political Weekly, 11, 843-46.

Case, A. (2000). Income Distribution and Expenditure Pattern in South Africa, Paper Prepared for the Conference on Poverty and the International Economy, organized by World Bank and Swedish Parliamentary Commission of Global Development, Stockholm, October 20-21.

Dercon, S. (2001). Economic Reform, Growth and the Poor: Evidence from Rural Ethiopia. CSAE Working Paper Series. 2001-08, Centre for the Study of African Economies, University of Oxford.

Dollar, D. \& Kraay, A. (2000). Growth Is Good for the Poor. Mimeo, World Bank, Washington, D.C.

Dollar, D. \& Kraay, A. (2001). Trade, Growth and Poverty. Finance \& development, 38(3), 16-19.

Dollar, D. \& Kraay, A. (2002). Growth is Good for the Poor. Journal of Economic Growth, 7, 195-225

Dollar, D. \& Kraay, A. (2004). Trade, Growth and Poverty. Economic Journal, 114(22).

Dreze, J. \& Sen, A. (1990). Hunger and Public Action. Oxford Clarendon Press

Federal Republic of Nigeria (FRN). (1996). Socio-economic Profile of Nigeria: Abuja, Federal office of Statistics.

Gandolfo, G. (1981). Qualitative Analysis and Econometric Estimation of Continuous Time Dynamic Models. North Holland, Amsterdam 1, 2.

Gunduz, L. (2000). Monetary Transmission and Bank Lending in Turkey. Paper presented at the International Conference on Banking, financial market and the Economics of the Middle East and North Africa". LUA Byblos/Lebanon, May 23-25. 
Hacker, T. \& Hatemi, J. (2008). Optimal lag-length choice in stable and unstable VAR models under situations of homosexuality and ARCH. Journal of Applied Statistics, 35(6), 601-615.

Harsch, E. (2006). Combating Inequality in Africa; Lessen Inequalities to Reduce Poverty and Reach MDGs; says UN Africa. Afrca Renewal, pp 16.

Johansen, S. (1988). Statistical Analysis of Cointegrated Vectors. Journal of Economic Dynamics and Control, $12,231-254$.

Johansen, S. \& Juselius, K. (1990). Maximum Likelihood Estimation and Inferences on Cointegration-with Application to the Demand for Money. Oxford Bulletin of Economics and Statistics, 52, 169-210.

Khor, M. (2000). Rethinking Liberalisation and Reforming The WTO. Paper Presented at the World Economic Forum at Davos, Switzerland, in January.

Knight, J. (2002). The Impact of Trade Liberalisation on Higher Education: Policy Implication. Globalisation: What Issues are at Stake For Universities? Universte Laval, Quebec, Canada.

Kuji, L. T. D. (2002). Comprehensive Review of The Nigerian Customs and Excise Tariffs 1995- 2001 : Implications for Nigeria of The ECOWAS Common External Tariffs and Nigeria's Obligations/Commitments under WTO, ECOWAS, AGOA and ACP-EU

Lanchovichina, E., Nicita, A. \& Soloaga, I. (2001). Trade Reform and Household Welfares: The case of Mexico. Policy Research Working Paper 2667, World Bank Development Research Gtoupon Trade.

Mbabazi, J., Morrissey, 0. \& Milner, C. (2001). Are Inequality and Trade Liberalization influences on growth and poverty? WIDER Discussion Paper, DP2001/132.

Miyamoto, K. (2003). Human Capital Formation and Foreign Director Investment in Developing Countries Development Centre Working Paper No. 211 (Formerly Technical paper No. 211) July 2003. DEV/DOC09

Nayaar, B. R. (1997). The Political Economy of India's Economic Performance since 1947, in C. Steven La (ed.), The India Handbook, Chicago and London: Fitzroy Dearborn Publishers. Pp. 37-61.

Nanna, K. (2002). Inflation Pressures and Continuous Fall in Foreign in Nigeria. Central Bank of Nigeria Publication, 4, 34-49, CBN Press Ltd., Nigeria.

Sanusi, S. L. (2001). Monetary Policy Expansion. Central Bank of Nigeria Publication, 171, 64-79, CBN Press Ltd., Nigeria.

Nwafor, M., Kanayo, O. \& Adenikinju, L. (2005). The Impact of Trade Liberalisation on Poverty in Nigeria: Dynamic Simulations in a CGE Model. Interim Report to the Poverty and Economic Policy (PEP) Research Network. First Draft April, 2005.

Nwaobi, G. C. (1999). Money and Output, Interaction in Nigeria: an Econometric Investigation using Multivariate Cointegration Technique. CBN Economic and Financial Review, 37(3), 44 - 76.

Ogun, T. P. (2010). Infrastructure and Poverty Reduction: Implications for Urban Development in Nigeria. Urban Forum. published online :29 May 2010 Springer Science Media B.V. vol. 21:249-266.

Okojie, C. E. E. (2002). Gender and Education as Determinants of Household Poverty in Nigeria. UNI-WIDER Discussion Paper: No 2002/37, Helsinki.

Olofin, A. (2001). A Computable General Equilibrium Model of Nigeria." Trade Competitivenesss. CEAR Research Paper No 2001/01,CEEAR, Ibadan.

Oyejide, A. T. (2002). Monetary Policy and its Effects on the Nigerian Economy: Proceedings of Nigeria Economic Society one-day's seminar held in Lagos.

Rajan, S. R. (2002). Trade Liberalisation and Poverty: Revisiting the Age-Old Debate. Economic and Political Weekly, 37(49), 4941-4946.

Ravallion, M. \& Datt, G. (1996). How Important to India's Poor is the Sectoral Composition of Economic Growth?' World Bank Economic Review, 10(1), 1-25.

Rodrik, D. (2000). Comments on Trade, Growth and Poverty. By D. Dollar and A. Kraay. Paper Presented at the American Economic Association Meeting. Boston MA 7-9 January.

Sachs, J. D. \& Warner, A. M. (1995). Economic Reforms and the Process of Global Integration. Brookings Papers on Economic Activity, 2, 1-118.

Saibu, O. M. (2004).Openness and Economic Growth in Nigeria: Further Evidence on Causality Issue. South African Journal of Economics and Management Sciences (SJEMS). Vol.7 no. pp. 115-131, Pretoria, South Africa. 
Soludo, C. C. (2008). Financial Globalization and Domestic Monetary Policy: Whither The Economics for the 21st Century? Inaugural Lecture, published by the University of Nigeria Senate Ceremonials Committee.

Tendulkar, S. D. (1998).Indian Economic Policy Reforms and Poverty: An Assessment. In I.J.Ahluwalia and I.M.D. Little (eds). India's Economic Reforms and Development Essays for Manmohan Singh Delhi: Oxford and New York: Oxford University Press.

Todaro, M. P. (1997). Economic Development. Reading Mass, Addison-Wesley.

UNCTAD. (1997).Trade and Development Report. United Nations New York and Geneva

UNCTAD. (1999).Trade and Development Report. United Nations New York and Geneva

United Nations. (1997). Human Development Report. New York Oxford University PressUwatt Bill (2003), Globalisation and Economic Growth: The African Experience. Globaisation and Africa's Economic Development. Selected papers for the 2003.annualconferene of the Nigeria Economic society. 